\title{
Occipital Headache Associated with C1 Hypoplasia
}

\author{
C1 Hipoplazisi ile İlişkili Oksipital Baş A ̆grısı
}

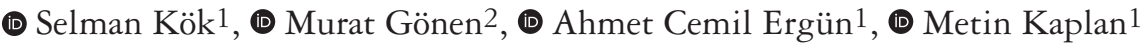 \\ ${ }^{1}$ Firat University Faculty of Medicine, Department of Neurosurgery, Elazig, Turkey \\ ${ }^{2}$ Firat University Faculty of Medicine, Department of Neurology, Elazig, Turkey
}

Keywords: Atlas, hypoplasia, cervicogenic headache

Anahtar Kelimeler: Atlas, hipoplazi, servikojenik baş ağrısı

Dear editor,

Atlas (C1) hypoplasia is a rare cause of occipital headache (1). Presented herein are three patients with $\mathrm{C} 1$ hypoplasia who were diagnosed with an occipital headache.

Patient 1: A 30-year-old male patient presented with numbness in the right arm and headache radiating to the neck for 8 years. The patient had hypoesthesia in the C4-T1 dermatome of the right upper extremity, and deep tendon reflexes were bilaterally hyperactive. The cervical computed tomography (CT) imaging revealed an $11 \mathrm{~mm}$ anteroposterior diameter of the spinal canal at the $\mathrm{C} 1$ level. The sagittal magnetic resonance imaging (MRI) revealed a spinal canal diameter of $8 \mathrm{~mm}$. T2-weighted MRI showed hyperintense areas consistent with myelopathy in the cord at the $\mathrm{C} 1$ level. The preoperative visual analog scale (VAS) score was 9. Post-operative headache was completely resolved (Table 1).

Patient 2: A 31-year-old female patient was admitted with complaints of headache radiating to the neck and right hemicranial numbness for 10 years. Neurological examination was normal. The cervical CT revealed a $9 \mathrm{~mm}$ anterior-posterior diameter of the spinal canal at the $\mathrm{C} 1$ level. The sagittal MRI revealed an $8 \mathrm{~mm}$

\begin{tabular}{|c|c|c|c|c|c|c|}
\hline Patients & Patient 1 & & Patient 2 & & Patient 3 & \\
\hline Gender & $\mathrm{M}$ & & $\mathrm{F}$ & & $\mathrm{F}$ & \\
\hline Canal diameter & $8 \mathrm{~mm}$ & & $8 \mathrm{~mm}$ & & $9 \mathrm{~mm}$ & \\
\hline $\begin{array}{l}\text { HA frequency } \\
\text { Day per week - B/A }\end{array}$ & $7 /-$ & - & $5 /-$ & - & $4 / 1$ & -- \\
\hline $\begin{array}{l}\text { Analgesic use } \\
\text { Number per week- B/A }\end{array}$ & 8/- & - & 4/- & - & $6 / 1$ & \\
\hline
\end{tabular}

Address for Correspondence/Yazışma Adresi: Selman Kök MD, Firat University Faculty of Medicine, Department of Neurosurgery, Elazig, Turkey Phone: +90 5448777993 E-mail: drselmankok@ gmail.com ORCID: orcid.org/0000-0003-2122-5295 Received/Geliş Tarihi: 13.04 .2020 Accepted/Kabul Tarihi: 13.08 .2021

${ }^{\circ}$ Telif Hakkı 2021 Türk Nöroloji Derneği

Türk Nöroloji Dergisi, Galenos Yayınevi tarafından basılmıştır. 
anteroposterior diameter of the spinal canal. T2-weighted MRI showed hyperintense areas in the cord at the $\mathrm{C} 1$ level (Figure 1,2). The preoperative VAS score was 9. The postoperative headache was completely resolved (Table1).

Patient 3: A 42-year-old female patient presented with complaints of headache radiating to the neck and numbness in the arms for 15 years. Neurological examination was normal. The cervical CT revealed an $11 \mathrm{~mm}$ anteroposterior diameter of the spinal canal at the $\mathrm{C} 1$ level and $9 \mathrm{~mm}$ in the sagittal MR, without myelopathy. The preoperative VAS score was 7 . The postoperative 3rd-month VAS score was 1 (Table 1).

Occipital headache accounts for $15-20 \%$ of all chronic and recurrent headaches (2). The source of pain is often the $\mathrm{C} 1-\mathrm{C} 3$ spinal nerves, C0-C3 intervertebral joints, dura mater, or bone structures (3). However, its symptoms and clinical overlap with
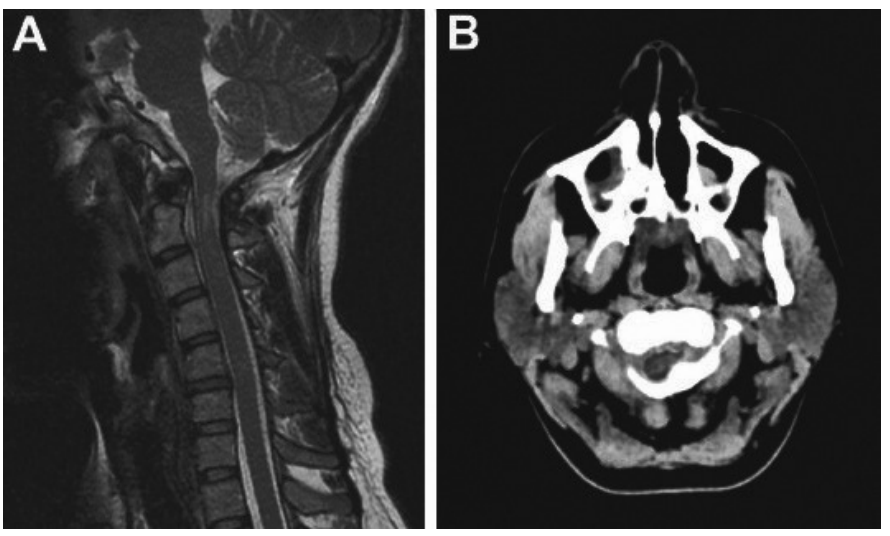

Figure 1. (A) Preoperative sagittal T2-weighted MRI; stenosis and myelopathy are observed at the $\mathrm{C} 1$ level. (B) Preoperative tomography image; $\mathrm{C} 1$ hypoplasia and the consequent narrowing of the canal (patient 2)

MRI: Magnetic resonance imaging, C1: Atlas
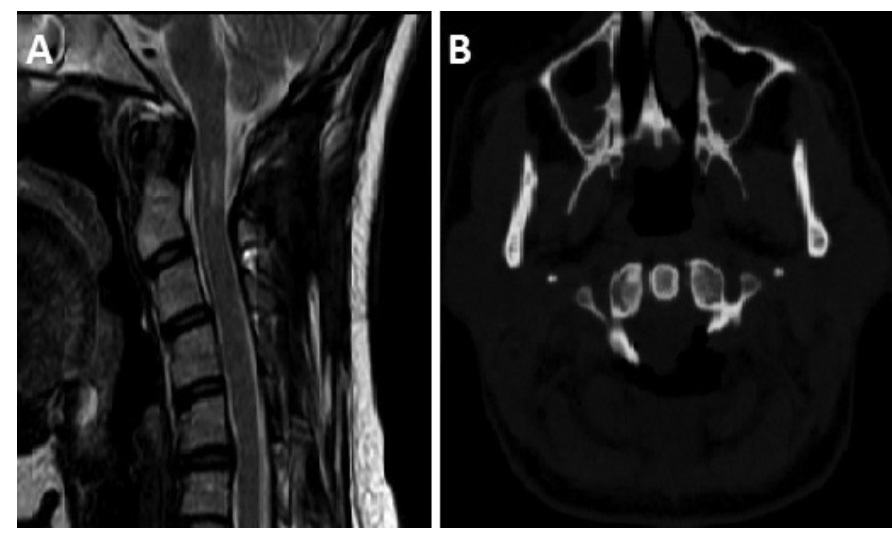

Figure 2. After C1 laminectomy, the canal enlarges. (A) Postoperative sagittal T2-weighted MRI; (B) postoperative axial tomography image (patient 2)

MRI: Magnetic resonance imaging, C1: Atlas other headache forms lead to difficulties in diagnosis and to misdiagnosis in $\sim 50 \%$ of the patients (1).

C1 hypoplasia is a rare condition that causes spinal stenosis, myelopathy, and occipital headache. C1 has three ossification centers originating from the rostral part of the first sclerotome (1). These three primary ossification centers are rarely far enough from each other (4). This causes hypoplasia and narrowing of the canal diameter.

The normal sagittal spinal canal diameter is $16-25 \mathrm{~mm}$ at the C1 level. Spinal stenosis is considered when the canal diameter is $<14 \mathrm{~mm}$. A canal diameter of $10 \mathrm{~mm}$ or less in patients poses a risk in the myelopathy clinical manifestation development (5). In most patients, the diagnosis is delayed because the narrowing does not cause serious neurological findings for a long time. The literature reported that posterior arch removal of the $\mathrm{C} 1$ lamina and decompression is effective in the regression of symptoms caused by $\mathrm{C} 1$ hypoplasia (1). In our three patients, clinical symptoms significantly improved after removal of the $\mathrm{C} 1$ posterior arch and atlantooccipital membrane.

In conclusion, patients with occipital headaches, which are resistant to medical therapy, should be evaluated for $\mathrm{C} 1$ hypoplasia. Patients should be considered as a whole while examining the radiological images, and the craniocervical junction should not be ignored. Surgical removal of the $\mathrm{C} 1$ posterior arch, atlantooccipital membrane, and surrounding degenerative ligaments with a posterior approach and stenosis relief is a safe and effective treatment method for occipital headache.

\section{Ethics}

Informed Consent: Consent form was obtained from the patients.

Peer-review: Externally and internally peer-reviewed.

\section{Authorship Contributions}

Surgical and Medical Practices: S.K., A.C.E., M.K., Concept: S.K., M.K., Design: S.K., A.C.E., Data Collection or Processing: S.K., M.G., Analysis or Interpretation: S.K., M.G., M.K., Literature Search: S.K., Writing: S.K.,

Conflict of Interest: No conflict of interest was declared by the authors.

Financial Disclosure: The authors declared that this study received no financial support.

\section{References}

1. Duz B, Kaplan M, Tehli Ö, Kahraman S. Cervical myelopathy due to a hypoplastic atlas. Neurosurg Q 2008;18:292-293.

2. Rubio-Ochoa J, Benítez-Martínez J, Lluch E, et al. Physical examination tests for screening and diagnosis of cervicogenic headache: a systematic review. Man Ther 2016;21:35-40.

3. Biondi DM. Cervicogenic headache: a review of diagnostic and treatment strategies. J Am Osteopath Assoc 2005;105(4 Suppl 2):16S-22S.

4. Urasaki E, Yasukouchi H, Yokota A. Atlas hypoplasia manifesting as myelopathy in a child. Neurol Med Chir 2001;41:160-162.

5. May D, Jenny B, Faundez A. Cervical cord compression due to a hypoplastic atlas. J Neurosurg 2001;94(Suppl 1):133-136. 